\title{
KEWENANGAN HAKIM UNTUK MENILAI ALAT BUKTI DALAM HUKUM ACARA PERDATA
}

\author{
Eka Susylawati
}

\begin{abstract}
Abstrak : Dalam melakukan pembuktian di muka pengadilan, pihakpihak yang berperkara dapat mengemukakan fakta-fakta yang bisa dijadikan dasar untuk meneguhkan hak perdatanya, maupun untuk membantah hak perdata pihak lain. Dan fakta-fakta tersebut haruslah disertai dengan alat-alat bukti, yang telah ditentukan secara limitatif dalam HIR/R.Bg yakni bukti tulisan, saksi, persangkaan, pengakuan dan sumpah. Dalam melakukan pemeriksan hakim haruslah mengindahkan alat-alat bukti tersebut di atas. Namun walaupun hakim terikat kepada alat-alat bukti, hakim juga memiliki kebebasan untuk menilai alat-alat bukti yang diajukan di persidangan dalam rangka tercapainya putusan yang berkeadilan. Kebebasan hakim tersebut tersebut teramat penting, karena alat-alat bukti yang ada saat ini tidak mampu lagi memenuhi perkembangan masyarakat, khususnya dalam pembuktian hukum acara perdata
\end{abstract}

\section{Pendahuluan}

Pada kodratnya manusia diciptakan oleh Tuhan yang Maha Kuasa tidak dapat melepaskan diri dengan orang lain sehingga manusia hidup dengan lainnya (bermasyarakat).

Dan di dalam kehidupan masyarakat tersebut, tiap-tiap individu memiliki kepentingan yang berbeda antara yang satu dengan yang lainnya. Dan ada kalanya terjadi benturan kepentingan, yang akan menimbulkan sengketa. Untuk menghindari hal tersebut maka perlu adanya norma-norma atau rambu-rambu kehidupan, yakni suatu ketentuan atau kaidah hukum, yang nantinya harus ditaati. Norma hukum amat berperan sekali dalam mengatur perilaku manusia dalam hidup bermasyarakat.

Dengan adanya norma hukum maka setiap orang diharuskan untuk bertingkah laku sedemikian rupa, sehingga kepentingan anggota masyarakat lainnya akan terjaga dan dilindungi dan apabila 


\section{Kewenangan Hakim Untuk Menilai Alat Bukti Dalam Hukum Acara Perdata}

kaidah hukum tersebut dilanggar, maka kepada yang bersangkutan akan dikenakan sanksi. ${ }^{1}$

Norma hukum sebagai salah bidang ilmu, memiliki dua bentuk yakni hukum materiil dan hukum formil. Hukum yang mengatur hak dan kewajiban diatur dalam hukum perdata materiil, sedangkan hukum yang menentukan bagaimana melaksanakan hak-hak dan kewajiban diatur dalam hukum perdata formil, yang lazim pula disebut dengan hukum acara perdata.

Menurut Sudikno Mertokusumo, hukum acara perdata adalah peraturan hukum yang mngatur bagaimana caranya menjamin ditaatinya hukum perdata materiil dengan perantaraan hakim. ${ }^{2}$ Sedangkan Retnowulan Sutantio mengartikan sebagai kaidah hukum yang menentukan dan mengatur cara bagaimana melaksanakan hakhak dan kewajiban-kewajiban perdata sebagaimana yang diatur dalam hukum perdata materiil. ${ }^{3}$

Tujuan dari hukum acara baik hukum acara perdata maupun hukum pidana untuk mencegah perbuatan main hakim sendiri (eigenrichting) sehingga dengan adanya hukum acara, masyarakat akan memperoleh perlindungan hukum yang diberikan oleh lembaga peradilan. Dengan adanya hukum acara perdata diharapkan tercipta ketertiban dan kepatuhan hukum dalam masyarakat. ${ }^{4}$

Di dalam hukum acara perdata terdapat tiga tahap kegiatan yang harus dilakukan secara beraturan 5 yakni:

\footnotetext{
${ }^{1}$ Salah satu yang membedakan norma hukum dengan norma yang lain (kesusilaan, kesopanan, dan agama) adalah sanksi. Memang ada yang berpendapat bahwa norma agama juga mengenal sanksi. Namun pemberian sanksi pada norma hukum akan langsung dikenakan kepada pelanggarnya.

2 Sudikno Mertokusumo, Hukum Acara Perdata Indonesia (Yogyakarta: Liberty, 1993) hlm. 2

${ }^{3}$ Retnowulan Sutantio, Hukum Acara Perdata Dalam Teori dan Praktik (Bandung: Mandar Maju, 1977), hlm. 1.

${ }^{4}$ Riduan Syahrani, Hukum Acara Perdata di Lingkungan Peradilan Umum (Jakarta: Pustaka Kartini, 1988) hlm.7.

${ }^{5}$ Sifatnya wajib karena hukum acara perdata pada hakikatnya bersifat mengikat dan memaksa (imperatif). Tidak hanya kepada pihak-pihak saja tetapi juga kuasa hukum dan hakim yang memeriksa suatu perkara. Lihat M. Nasir, Hukum Acara Perdata (Jakarta: Djambatan, 2003) hlm. 5.
} 


\section{Eka Susylawati}

1. Tahap Pendahuluan, yang merupakan tahap persiapan. Pada tahap ini meliputi membuat surat gugatan, mendaftarkan gugatan di pengadilan, membayar biaya perkara dan sebagainya.

2. Tahap menentukan, yang meliputi pemeriksaan peristiwa, pembuktian dan menjatuhkan putusan.

3. Tahap pelaksanaan, merupakan tahap pelaksanaan putusan (eksekusi) yang telah dijatuhkan oleh hakim.

Diantara ketiga tahap di atas, tahap kedualah yang paling menentukan, karena pada tahap kedua merupakan tahap pembuktian, dimana pada tahap ini pihak-pihak akan meyakinkan hakim tentang kebenaran dalil-dalil yang dikemukakan dalam suatu persengketaan. ${ }^{6}$

Pasal 163 HIR/283 R.Bg menyatakan bahwa barang siapa yang menyatakan mempunyai hak atau menyebutkan suatu kejadian unutk meneguhkan haknya itu, maka orang tersebut haruslah membuktikan adanya hak atau adanya kejadian itu. Pasal ini lebih dipertegas lagi dengan Yurisprudensi Mahkamah Agung tanggal 11 September 1975, Nomor 540 K/Sip/1972 yang menyatakan bahwa apabila tergugat menyangkal, maka penggugat yang harus membuktikan dalil-dalilnya

Apabila yang menyatakan mempunyai barang sesuatu hak tidak dapat membuktikan hak atau peristiwa yang diajukan, maka hakim terpaksa akan menyatakan bahwa hak itu tidak akan terbukti. Selain itu haruslah pula dibuktikan oleh orang yang mempunyai hak adalah hal-hal yang merupakan dasar dari haknya itu.

Dengan demikian pembuktian itu hanya dipergunakan pada waktu ada persengketaan atau adanya perkara di muka hakim pengadilan, dan dalam arti terbatas pembuktian hanya diperlukan apabila sesuatu yang dikemukakan oleh penggugat disangkal kebenarannya oleh tergugat, dan penggugat dibebankan untuk membuktikan atas dalil-dalil hak tersebut.

Dalam hukum pembuktian, hakim akan menentukan apa yang harus dibuktikan dan pihak mana yang harus memberi bukti, artinya hakim akan menentukan pihak mana (tergugat atau penggugat) yang akan memikul tentang beban pembuktian. Dalam praktik apabila

${ }^{6}$ R Subekti, Hukum Acara Perdata (Jakarta: Binacipta, 1982) hlm. 78. 


\section{Kewenangan Hakim Untuk Menilai Alat Bukti Dalam Hukum Acara Perdata}

para pihak mempunyai alasan masing-masing atas dalil-dalilnya maka beban untuk pembuktian dilimpahkan kepada para pihak yang berperkara. Kecuali apabila dalil-dalil penggugat ditolak kebenarannya oleh tergugat, maka beban pembuktian dibebankan pada penggugat.

Berbeda dengan azas dalam hukum acara pidana, seseorang tidak dapat dipersalahkan melakukan tindak pidana, kecuali apabila terdapat bukti-bukti yang sah, dan hakim mempunyai keyakinan bahwa terdakwa memang salah. Dan untuk mendapatkan kenyataan dan keyakinan ini hakim membutuhkan alat-alat bukti guna menggambarkan lagi kenyataan-kenyataan yang sudah lampau itu. Selain itu perbedaan yang lain, dalam hukum acara pidana menetapkan kebenaran terhadap setiap orang, sedangkan bukti dalam suatu perkara perdata hanya menetapkan kebenaran terhadap pihak yang berperkara.

\section{Alat Bukti Dalam Hukum Acara Perdata}

Berdasarkan ketentuan pasal $164 \mathrm{HIR} / 284 \mathrm{RBg}$ dan pasal 1866 KUH Perdata, terdapat (5) lima alat bukti dalam perkara perdata di Indonesia. Menurut pasal-pasal tersebut dalam hukum acara perdata hakim terikat pada alat-alat bukti yang sah. Hal ini berarti bahwa hakim hanya boleh mengambil keputusan berdasarkan alat bukti yang ditentukan undang-undang saja. Adapun alat bukti tersebut adalah sebagai berikut:

\section{Bukti Surat}

Bukti surat merupakan alat bukti tertulis yang diatur dalam pasal 165- $167 \mathrm{HIR} /$ pasal 285-305 RBg. Alat bukti tulisan merupakan segala sesuatu yang memuat tanda-tanda bacaan yang dimaksudkan untuk mencurahkan pikiran dan isi hati seseorang yang ditujukan untuk dirinya dan atau orang lain yang dapat digunakan untuk alat pembuktian.

Sedangkan menurut bentuknya alat bukti tertulis dibagi dua yakni, 1. surat akta dan 2. surat bukan akta.7 Yang membedakan

${ }^{7}$ M Nasir, Hukum Acara Perdata (Jakarta : Djambatan 2003) hlm. 151. 


\section{Eka Susylawati}

antara yang akta dan yang bukan, adalah ketegasan atau kejelasan dari isinya. Apabila surat yang tertanggal dan diberi tanda tangan tersebut memuat keterangan tentang kejadian yang menjadi dasar suatu hak/perikatan yang dapat dipergunakan dalam pembuktian, maka hal tersebut disebut akta. Dan sebaliknya jika tidak terdapat hal tersebut tidak dapat dikategorikan sebagai akta.

\section{Bukti Saksi}

Kesaksian adalah kepastian yang diberikan kepada hakim dalam persidangan tentang kejadian-kejadian yang dilihat, dialami sendiri, mengenai sesuatu yang disengketakan dengan jalan menerangkan secara lisan dan secara pribadi oleh orang yang bukan salah satu pihak yang dalam berperkaran itu. Adapun alat bukti saksi diatur dalam pasal 168 s/d 172 HIR, pasal 306 s/d 309 R.Bg dan pasal 1895, 1902 s/d 1908 BW.

Pembuktian dengan saksi dalam praktik lazim disebut kesaksian. Dalam hukum acara perdata pembuktian peranan saksi memiliki peranan

yang sangat penting, terutama apabila tidak ada bukti tertulis, dimana orang berhubungan dengan saling mempercayai. Oleh karena bukti surat tidak ada maka pihak-pihak akan berusaha untuk mengajukan saksi yang membenarkan atau menguatkan dalildalilnya di persidangan.

Seorang saksi dapat secara kebetulan melihat atau mengalami sendiri peristiwa yang harus dibuktikan di muka hakim, ada pula yang memang sengaja diminta untuk menyaksikan suatu perbuatan hukum yang sedang dilakukan, misalnya menyaksikan jual beli tanah, pembagian waris dan sebagainya.

Pembuktian dengan saksi hendaknya digunakan lebih dari satu saksi, sebab keterangan seorang saksi saja tanpa didukung oleh alat bukti yang lain, tidak dianggap sebagai bukti, artinya satu saksi dianggap bukan saksi (unus testis nulus testis) yang diatur dalam pasal 169 HIR/306 R.Bg. ${ }^{8}$

Dalam pembuktian dengan saksi, hal ini baru dianggap sempurna apabila ada dua orang atau lebih namun demikian meskipun ada dua orang atau lebih saksi, belum tentu suatu peritiwa

\footnotetext{
${ }^{8}$ Ibid. hlm. 165.
} 


\section{Kewenangan Hakim Untuk Menilai Alat Bukti Dalam Hukum Acara Perdata}

dapat dikatakan menyakinkan, apabila hakim tidak mempercayai kejujuran dari keterangan para saksi. Dan walaupun keterangan para saksi yang diajukan saling menguatkan, tetapi keterangan tersebut bertentangan dengan logika, maka dengan keterangan tersebut dianggap tidak dapat dibuktikan kebenaran dalil gugatan penggugat.

Di dalam praktik mungkin terjadi yakni seorang saksi yang sangat diperlukan dan telah diminta datang oleh salah satu pihak, tidak mau menghadap di muka persidangan. Apabila hal ini terjadi maka hakim dapat memerintahkan agar saksi tersebut dihadapkan dan jika perlu

dengan bantuan polisi, artinya saksi tersebut dipaksa untuk menghadap

dan memberikan keterangan. Adapun kewajiban saksi adalah sebagai berikut : 9

a. Kewajiban untuk menghadap di persidangan setelh dipanggil secara patut. Hal ini dapat disimpulkan dari pasal $140 \mathrm{~s} / \mathrm{d} 141$ HIR dan pasal 166 s/d 167 R.Bg, yang menentukan adanya sanksi bagi saksi yang tidak mau datang setelah dipanggil secara patut.

b. Kewajiban untuk bersumpah menurut agamanya masing-masing, dengan harapan saksi akan betul-betul memberikan keterangan yang sebenarnya.

c. Kewajiban untuk memberikan keterangan.

\section{Alat Bukti Persangkaan}

Persangkaan sebagai alat bukti diatur dalam pasal $173 \mathrm{HIR} / 310$ R.Bg dan pasal 1915 s/d 1922 KUH Perdata. Persangkaan adalah kesimpulan yang diambil dari suatu peritiwa yang telah terbukti ke arah suatu peristiwa yang belum terbukti. Dalam hal ini yang berhak menarik kesimpulan tersebut adalah hakim dan undang-undang. Jika yang menarik kesimpulan tersebut hakim, maka persangkaan tersebut disebut persangkaan hakim, sebaliknya bila yang menarik

\footnotetext{
${ }_{9}^{9}$ Kurdianto, Sistem Pembuktian Hukum Acara Perdata (Dalam Teori dan Praktek), (Surabaya: Usaha Nasional ,1991) hlm.55.
} 


\section{Eka Susylawati}

kesimpulan adalah undang-undang, maka persangkaan tersebut disebut persangkaan undang-undang. ${ }^{10}$

Pembuktian dengan persangkaan dilakukan apabila terdapat kesukaran untuk mendapatkan saksi-saksi yang melihat atau mengalami sendiri peristiwa yang harus dibuktikan. Misalnya dalam suatu perkara

gugatan perceraian yang didasarkan kepada perzinahan adalah sangat sulit sekali, karena sulitnya mendapatkan saksi yang telah melihat sendiri perbuatan zina itu, Untuk membuktian peristiwa perzinahan hakim harus menggunakan alat bukti persangkaan.

Dibandingkan dengan persangkaan undang-undang, persangkaan hakim sebagai alat bukti memiliki kekuatan pembuktian yang bebas. Dalam hal ini kekuatan pembuktian apa yang akan diberikan kepada persangkaan hakim tertnetu, apakah sebagai alat bukti yang memiliki kekuatan sempurna atau alat bukti permulaan atau sama sekali tidak memiliki kekuatan sama sekali, diserahkan sepenuhnya kepada penilaian hakim. Biasanya untuk satu persangkaan hakim tidaklah dianggap memadai untuk menganggap suatu dalil tersebut terbukti. Persangkaan hakim baru dianggap sebagai alat bukti yang lengkap apabila saling berhubungan dengan persangkaan hakim lain yang terkait dengan perkara itu. Hal ini berbeda dengan persangkaan undang-undang, yang tidak memberikan kebebasan kepada hakim seperti di atas, karena persangkaan undang-undang haruslah didasarkan atas suatu ketentuan khusus undang-undang, yang dihubungkan dengan perbuatan-perbuatan atau peristiwa-peristiwa tertentu. ${ }^{11}$

\section{Alat bukti pengakuan}

Pengakuan adalah keterangan sepihak, baik tertulis maupun lisan, yang secara tegas dan nyata diterangkan oleh salah satu pihak atau lebih dalam penyelesaian perkara di persidangan, yang berisi pembenaran sebagian atau seluruhnya terhadap sutu peristiwa, hak atau hubungan hokum yang diajukan oleh pihak lawan, yang mengakibatkan tidak perlu lagi dilakukan pemeriksaan lebih lanjut

\footnotetext{
${ }^{10}$ R Subekti, hlm. 107.

${ }^{11}$ Kurdianto, hlm.57.
} 


\section{Kewenangan Hakim Untuk Menilai Alat Bukti Dalam Hukum Acara Perdata}

(pasal 174 s/d 176 HIR, 311 s/d 313 R.Bg dan pasal 1923 s/d 1928 KUH Perdata).

Pengakuan yang dilakukan secara diam-diam tidaklah memberikan kepastian kepada hakim tentang kebenaran suatu peristiwa. HIR masih bersifat ambiguitas ${ }^{12}$ dalam hal ini, pada suatu ketika pengakuan secara diam-diam dapat diterima dan pada saat yang lain HIR bersifat menolak pengakuan diam-diam tersebut.

Pengakuan dibedakan menjadi dua yakni pengakuan yang dilakukan di depan sidang dan pengakuan yang dilakukan di luar persidangan. Keduanya mempunyai nilai pembukatian yang berbeda. Menurut pasal $174 \mathrm{HIR}$, pengakuan yang diucapkan di hadapan hakim menjadi bukti yang cukup untuk memberatkan orang yang mengaku tersebut, baik diucapkan sendiri maupun dilakukan oleh kuasanya. Sebaliknya dalam pasal 175 HIR, pengakuan yang dilakukan di luar persidangan diserahkan kepada pertimbangan hakim.

Dengan demikian pengakuan yang dilakukan di depan sidang mempunyai kekuatan bukti yang sempurna sedangkan pengakuan di luar sidang merupakan bukti bebas.

Pengakuan di depan sidang tidak boleh ditarik kembali,kecuali terdapat kekhilafan mengenai hal-hal yang telah terjadi. Suatu pengakuan di depan sidang dengan tertulis, kekuatan pembukatiannya disamakan sebagai suatu pengakuan secara lisan di depan sidang.

\section{Alat bukti sumpah}

Sumpah adalah suatu pernyataan yang hikmat dan diberikan atau diucapkan pada waktu memberi janji atau keterangan dengan mengingat akan sifat Yang Maha Kuasa dan percaya bahwa siapa yang memberi keterangan atau janji yang tidak benar akan mendapat hukuman dari yang Kuasa. Dengan demikian sumpah adalah perbuatan formal yang terkait dengan agama dan keyakinan seseorang yang dipergunakan untuk proses yudisial. ${ }^{13}$

${ }^{12}$ M Nasir, hlm. 174.

13 Ibid. hlm. 178. 


\section{Eka Susylawati}

Dalam hukum acara perdata terdapat tiga macam sumpah yakni, sumpah pelengkap (suppletoir), sumpah pemutus (decisoir) dan sumpah penaksir (aestimatoir).

Sumpah pelengkap adalah sumpah yang diperintahkan oleh hakim karena jabatannya kepada salah satu pihak dalam rangka melengkap pembuktian peristiwa yang menjadi sengketa untuk dijadikan dasar putusan. Sumpah ini baru dapat dilaksanakan apabila terdapat pembuktian permulaan. Sumpah ini haruslah dilakukan dengan hati-hati karena pihak yang diperintahkan untuk bersumpah oleh hakim, dan pihak tersebut melakukankannya maka ia akan memenangkan perkara tersebut (memiliki kekuatan pembuktian yang sempurna).

Sumpah pemutus adalah sumpah yang dibebankan atas permintaan salah satu pihak kepada lawannya, karena tidak ada bukti sama sekali. Pihak yang minta lawannnya bersumpah disebut dengan deferent, dan pihak yang harus bersumpah disebut dengan delaat. Sumpah pemutus dibebankan kepada salah satu pihak kepada lawannya, dan apabila pihak lawan bersedia mengucapkan sumpah, maka lawan tersebut yang akan memenangkan perkara. Tetapi jika pihak lawan menolak untuk bersumpah dan mengembalikan sumpah tersebut kepada deferent, kemudian deferent menolak, maka hakim akan mengalahkan yang bersangkutan.

Sumpah penaksir adalah sumpah yang diperintahkan oleh hakim karena jabatannya kepada pihak penggugat untuk menentukan bentuk dan jumlah ganti rugi. Sumpah penaksir ini baru dapat dibebankan oleh hakim kepada penggugat bila telah dapat membuktikan haknya atas ganti

rugi, namun jumlah dan bentuknya belum pasti dan tidak bersedia cara lain untuk menentukan hak tersebut, selain dengan cara menaksir saja. Bagi hakim tidak ada kewajiban untuk membebani sumpah penaksir kepada penggugat. ${ }^{14}$

Tugas Hakim Dalam Acara Pembuktian

${ }^{14}$ Sudikno Mertokusumo, hlm. 180 


\section{Kewenangan Hakim Untuk Menilai Alat Bukti Dalam Hukum Acara Perdata}

Sudah dijelaskan sebelumnya bahwa pembuktian adalah proses persidangan yang terkait dengan alat bukti dan merupakan tahap yang paling menentukan. Dikatakan menentukan karena pembuktian akan menjadi dasar bagi hakim dalam mengadili dan memutuskan perkara di persidangan.

Dalam acara pembuktian, para pihak mengajukan peristiwaperistiwa dan fakta-fakta yang menjadi dasar dari gugatan penggugat dan jawaban tergugat. Hakim sebagai pemutus perkara, haruslah memahami benar peristiwa dan fakta yang diajukan.

Membuktikan adalah menyakinkan hakim tentang kebenaran dalil atau fakta yang diajukan oleh penggugat dan tergugat di pengadilan. Dengan demikian pembuktian hanya diperlukan dalam suatu sengketa atau perkara di hadapan hakim.

Tindakan membuktikan hanya diperlukan bila timbul suatu sengketa antara dua orang atau lebih. Sebagai contoh, selama tidak ada yang mengklaim bahwa tanah yang ditempati oleh Amir adalah milik orang lain, maka Amir tidak perlu membuktikannya dan mobil tersebut dianggap benar-benar miliknya.

Hakim merupakan alat perlengkapan dalam suatu negara hukum yang ditugaskan menetapkan hubungan hukum yang sebenarnya antara dua pihak yang terlibat dalam suatu sengketa. Dan pada akhirnya, hakimlah yang akan memutus sengketa tersebut.

Tugas hakim tersebut adalah menetapkan hukum secara spesifik atau menerapkan hukum. Dan biasanya dalam persidangan pihakpihak akan mengajukan dalil-dalil dan fakta yang bertentangan satu sama lain. Disinilah tugas hakim untuk memeriksa dan menetapkan dalil atau peristiwa manakah yang benar atau paling tidak mendekati kebenaran. Berdasarkan acara pembuktian, hakim dengan amar putusannya akan menentukan pihak yang akan dimenangkan dan pihak yang dikalahkan.

Dalam melaksanakan pemeriksaan tersebut, hakim harus mengindahkan aturan-aturan tentang pembuktian yang merupakan hukum pembuktian. Hakim dalam melaksanakan tugasnya, khususnya dalam acara pembuktian tidak diperkenankan hanya mengandalkan keyakinan saja, melainkan keyakinan tersebut haruslah didukung oleh kebenaran alat bukti yang diajukan oleh para 


\section{Eka Susylawati}

pihak. Dengan alat bukti maka kekurangpastian hukum dan kesewenang-wenangan akan dapat diminimalisir.

Fakta-fakta yang diajukan oleh pihak-pihak belum tentu semuanya penting bagi hakim untuk dijadikan dasar pertimbangan. Karenanya hakim harus dapat memisahkan fakta yang penting dan fakta yang tidak relevan dengan perkara. Dan hakim haruslah memfokuskan pada fakta yang penting karena fakta ini yang berkait dengan hukum pembuktian

Disamping itu, hakim juga diharuskan mengindahkan aturanaturan yang menjamin keseimbangan dalam pembebanan kewajiban membuktikan terhadap sengketa yang diperselisihkan. Sebab apabila beban pembuktian berat sebelah maka akan menimbulkan rasa tidak puas kepada pihak lawan. Dan ini sesuai dangan azas dalam hukum acara perdata bahwa "hakim haruslah mengadili kedua belah pihak" ${ }^{15}$

Dampak dari tidak adilnya hakim dalam keseimbangan pembuktian akan dapat menyebabkan pihak yang memperoleh kesempatan lebih sedikit, akan mengalami kekalahan dalam perkaranya.

Dengan demikian hukum pembuktian adalah merupakan serangkaian tata tertib yang harus dilaksanakan dalam mencari kebenaran dan keadilan di hadapan hakim.

\section{Penilaian Pembuktian Oleh Hakim}

Dalam acara pembuktian, alat bukti yang diajukan masih memerlukan penilaian lebih lanjut oleh hakim. Pertanyaannya sekarang, dalam menilai pembuktian apakah hakim bebas atau sebaliknya justru terikat kepada undang-undang. Untuk menjawab hal tersebut terdapat tiga teori, yang lazim berlaku pada hukum acara perdata yaitu: ${ }^{16}$

a. Teori pembuktian negatif

\footnotetext{
15 Azas ini merupakan salah satu azas terpenting dalam hukum acara perdata dan terkenal dengan audi et alteram partem, yang artinya hakim tidak diperbolehkan memihak dalam semua hal, terutama sekali dalam acara pembuktian.

${ }^{16}$ M Nasir, hlm. 145.
} 


\section{Kewenangan Hakim Untuk Menilai Alat Bukti Dalam Hukum Acara Perdata}

Menurut teori ini harus ada ketentuan-ketentuan yang mengikat yang sifatnya negatif, yakni tujuannya untuk membatasi hakim dalam acara pembuktian

b. Teori pembuktian positif

Teori ini menghendaki, disamping adanya larangan, hakim juga dibebani untuk melakukan sesuatu

c. Teori pembuktian bebas

Berbeda dengan teori negatif dan positif, pada teori ini tidak menghendaki adanya ketentuan-ketentuan yang mengikat hakim, sehingga penilaian pembuktian tergantung kepada hakim.

Bila kita bandingkan ketiga teori di atas dengan kondisi pada dunia peradilan Indonesia saat ini, maka sebagian besar para sarjana lebih menghendaki teori pembuktian yang lebih bebas (teori yang ke3).

Kebebasan dalam hukum pembuktian bertujuan untuk memberikan kelonggaran kepada hakim untuk benar-benar mencari kebenaran yang sejati, yang nantinya akan dipergunakan sebagai dasar membuat putusan akhir. Hal tersebut disebabkan alat-alat bukti yang telah ditentukan dalam HIR/R.Bg sudah tidak sesuai lagi dengan perkembangan masyarakat. Misalnya alat bukti sumpah, yang pada saat ini hampir tidak digunakan lagi dalam praktik di peradilan. Alat bukti sumpah merupakan pisau bermata dua karena jika digunakan dalam persidangan akan menentukan kemenangan atas suatu perkara. Padahal saat ini pada orang tertentu akan mudah sekali mengucapkan sumpah yang berisi oleh kebohongan (palsu).

Bagi orang yang beragama dan betul-betul paham akan makna dari sumpah, tidak akan mudah untuk memberikan keterangan yang tidak benar karena akan menyadari bahwa apabila memberikan keterangan yang tidak benar, ia akan mendapat laknat dari Yang Maha Kuasa. Namun terkadang ada orang yang tidak peduli atas sumpahnya, yang penting tujuannya tercapai. Karenanya hakim pada perkembangan sekarang, lebih menggunakan alat bukti tulisan dan saksi. Sedangkan alat bukti yang lain termasuk persangkaan dan pengakuan jarang dijadikan alat bukti di persidangan.

Selain sebab di atas, dalam perkembangan praktik di dunia peradilan, selain 5 (lima) alat bukti yang telah ditentukan dalam 


\section{Eka Susylawati}

HIR/R.Bg, juga dikenal alat bukti yang baru yakni "pengetahuan hakim". Pengetahuan hakim adalah hal atau keadaan yang diketahuinya sendiri oleh hakim selama persidangan atau ketika hakim melakukan pemeriksaan setempat (decente). ${ }^{17}$

Secara umum, hakim bebas untuk melakukan penilaian pembuktian. Jadi yang menilai pembuktian yang merupakan penilaian terhadap kenyataan yang bersifat yudex factie 18 adalah hakim. Karenanya jika suatu perkara diteruskan sampai kasasi ke Mahkamah Agung maka Mahkamah Agung sebagai pengadilan tertinggi tidak akan melakukan penilaian pembuktian yang telah dilakukan oleh pengadilan sebelumnya.

Persoalannya Pasal 165 HIR/pasal 285 R.Bg menyatakan bahwa akta otentik merupakan alat bukti tertulis dan hakim terikat dalam melakukan penilaian, yang berarti bahwa akta tesebut tidak dapat dikesampingkan dalam persidangan. Dari isi pasal tersebut dapat ditarik kesimpulan bahwa hakim sulit mengenyampingkan, dan yang harus membuktikan adalah pihak yang menyangkalnya.

Sebaliknya hakim tidak wajib mempercayai seorang saksi, jika menurut keyakinannya kesaksian tersebut diliputi kebohongan. Apabila hal itu terjadi maka hakim dapat menolak atau tidak menerima keterangannya (pasal 172 HIR/Pasal 309 R.Bg). Dalam kaitannya dengan saksi, sebelumnya sudah dijelaskan bahwa ia wajib untuk memberikan kesaksian, jika memang dibutuhkan. Misalnya menolak, padahal ia betul-betul mengetahui akan peristiwa atau suatu hak, maka ia dapat dipaksa hadir ke persidangan oleh yang berwajib (polisi). Namun pemaksaan saksi seperti di atas pada umumnya terjadi pada ruang lingkup hukum pidana, sedangkan

\footnotetext{
${ }^{17}$ Decente adalah pemeriksaan mengenai perkara oleh hakim karena jabatannya yang dilakukan di luar gedung atau tempat kedudukan pengadilan. Hal ini dilakukan agar hakim dapat melihat dan mengamati sendiri secara nyata sehingga kepastian tentang duduk perkara. Pada decente biasanya dilakukan dalam sengketa batas tanah, letak gedung atau rumah dan sebagainya. Decente tersebut diatur di dalam padal 153 HIR.(lihat Sudikno Mertokusumo, Hukum Acara Perdata Indonesia (Yogyakarta: Liberty,1977) hlm.161.

${ }^{18}$ Yudex factie adalah pengadilan yang hanya memeriksa perkara perdata berdasarkan faktanya saja, dan di Indonesia yang termasuk yudex factie adalah pengadilan tingkat pertama dan tingkat kedua (banding)
} 


\section{Kewenangan Hakim Untuk Menilai Alat Bukti Dalam Hukum Acara Perdata}

dalam hukum acara perdata dalam menghadirkan saksi merupakan urusannya sendiri dari pihak-pihak. Ini membuktikan bahwa apa yang tertulis di dalam HIR sudah tidak berlaku di dalam masyarakat.

Dalam suatu perkara bukti dikatakan lengkap dan sempurna bila alat bukti yang diajukan para pihak dan dinilai oleh hakim telah memadai untuk memberikan kepastian tentang peristiwa yang menjadi sengketa. Dengan bukti tersebut hakim akan memiliki dasar yang cukup apakah akan mengabulkan gugatan penggugat ataupun tidak.

Dalam pembuktian, walaupun bukti yang diajukan oleh salah satu pihak sangatlah lengkap, masih dapat dilumpuhkan oleh pihak lainnya. Pembuktian oleh lawan tersebut adalah pembuktian untuk menyangkal atau membuktikan ketidakbenaran peristiwa yang diajukan. Disinilah perlu adanya pengetahuan, keterampilan dan keyakinan hakim (menunjukan terdapat kebebasan hakim untuk menilainya). 